\title{
Regional knowledge networks for Lifelong Learning
}

\author{
Frank Go \& Tom van Weert \\ Rotterdam School of Management, P. O. Box 1738, 3000 DR Rotterdam, The Netherlands. \\ Tel: + 3110408 1960, Fax: +31 10408 9011; Hogeschool van Utrecht, Cetis, Centre of \\ expertise for educational innovation and ICT, P. O. Box 85029, 3508 AA Utrecht, The \\ Netherlands
}

F.Go@fbk.eur.nl,http://www.fbk.eur.nl; t.vweert@cetis.hvu.nl,http://www.cetis.hvu.nl

\begin{abstract}
Why are particular communities performing economically better in knowledge economies? Under conditions of intense global competition and complexity it seems that better performing communities enable their members to cultivate human talent: they enable their members to learn. This allows these learning communities to shift resources out of low-wage activities into higher value adding activities, thus providing continued prosperity. The basis of this seems to be a capacity to develop a competitive edge through the application of advanced technology, knowledge and service. From an employment perspective, there is a dangerous mismatch between what the knowledge economy needs of higher education and the "competences" the latter delivers. Lifelong learning provides a paradigm shift to "learning activity undertaken throughout life, with the aim of improving knowledge, skills and competence, within a personal, civic, social and/or employment-related perspective". It provides higher education with the imagination to perceive its future anew, with an engagement to redefine itself in alignment with agile learning communities. It enables learning communities, of which higher education is an integral part, to perform economically better.
\end{abstract}

Key words: community stakeholders, economic perspective, employment perspective, learning communities, partnership, triple helix 


\section{KNOWLEDGE INTENSIVE ECONOMIES}

\section{Innovation as driving force}

During the past decade attention in literature given to knowledge has literally 'exploded'. The main reason for such interest is a major increase in the dynamics and complexity of the external environment in which organisations operate. Among the main causes are globalisation, the blurring of boundaries, technological advancement and de-regulation. It raises the issue: How to survive under conditions of 'hypercompetition? (D'Aveni 1994). The literature offers numerous concepts to achieve and sustain a competitive edge, including 'permanent innovation' (Janszen 2000), realisation of 'strategic fit' (Porter 1996) or 'one-to-one' marketing (Peppers \& Rogers 1993). The aforementioned concepts differ considerably in terms of both background and content. However, in each of the three concepts knowledge is a central theme. Individuals and organisations that possess relevant knowledge are able to develop relationships and innovate faster than their rivals. Therefore, knowledge is increasingly recognised as the most important production factor.

\section{The role and impact of ICT}

Information and Communication Technology (ICT) is becoming a ubiquitous tool both in the work place and at home. "The penetration of ICT within society has far reaching consequences for the organisation of labour and the demands put on the workers. Just as other technological innovations have in the past, ICT influences commercial organisations in three ways: by product innovation, by innovation of the production process and by changes in the organisation of labour." (WRR 2002; p. 146; authors' translation). As part of their professional environment, workers will have to deal with generic ICT-tools, including e-mail, browser, text processor. But, also discipline specific tools, such as Mathematica and SPSS, or profession specific tools, such as a patient database. The salient ICT applications that impact almost everyone's life are:

- Personal communication (finding and interacting with resources, organisations and people);

- Organisation of activities (planning, scheduling, monitoring);

- Information management (organising, storing, creating and sharing of information);

- Organisation of team and community learning (group work);

- Navigation systems (mobility guidance; business and leisure travel). 
A white paper from the Economist Intelligence Unit in co-operation with IBM (http://www.eiu.com) defines E-readiness as: the extent to which a country's business environment is conducive to Internet-based opportunities. E-readiness factors include:

- Connectivity and technology infrastructure

- Business environment

- Consumer and business adoption

- Legal and policy environment

- Social and cultural infrastructure

- Supporting e-services

Table 1. gives an overview of the e-readiness ranking 2002, showing a score for the USA, The Netherlands and the United Kingdom of more than 8 out of 10. This illustrates the fact that ICT plays a crucial role with regard to empowering people to express their creativity and supporting them to function in learning teams.

Table 1. E-readiness ranking 2002

\begin{tabular}{llll}
\hline Ranking 2002 & Top Ten & Score $(\max : 10)$ & Ranking 2001 \\
\hline 1 & USA & 8.41 & 1 \\
2 & Netherlands & 8.40 & 10 \\
3 & United Kingdom & 8.38 & 3 \\
$4 \mathrm{a}$ & Switzerland & 8.32 & 11 \\
$4 \mathrm{~b}$ & Sweden & 8.32 & 6 \\
5 & Australia & 8.30 & 2 \\
6 & Denmark & 8.29 & 9 \\
7 & Germany & 8.25 & 12 \\
8 & Canada & 8.23 & 4 \\
9 & Finland & 8.18 & 8 \\
$10 \mathrm{a}$ & Singapore & 8.17 & 7 \\
$10 \mathrm{~b}$ & Norway & 8.17 & 5 \\
& & & \\
\hline
\end{tabular}

The current technology on our desktop, in our homes and in learning communities provides a powerful toolbox that transcends traditional spatial boundaries. ICT implies being connected 'anytime' and 'anywhere', that is ICT affords access at work, both in the home and away-from-home and away-from-office. In summary, ICT has had fundamental consequences to our everyday lives. 


\section{Towards polyinclusion of work, learning and play}

Bell's (1988) observation of "an extraordinary historical and sociological shift in the nature of markets from places to networks" is echoed by Tapscott's (1996; p. 198): "work and learning overlap for a massive component of the workforce" and the statement that "Cyberspace enables us to move ourselves to parallel worlds or in time", raising the issue of the digital divide. In particular, the digital divide poses the issue how to optimally unlock the potential of 'moving bodies' and 'connecting minds' to gain access to material space, information space, mind space, and social space (Go \& van Fenema 2003), that affect both informal - and formal learning, and lead to patterns of polyinclusion. (Figure 1)

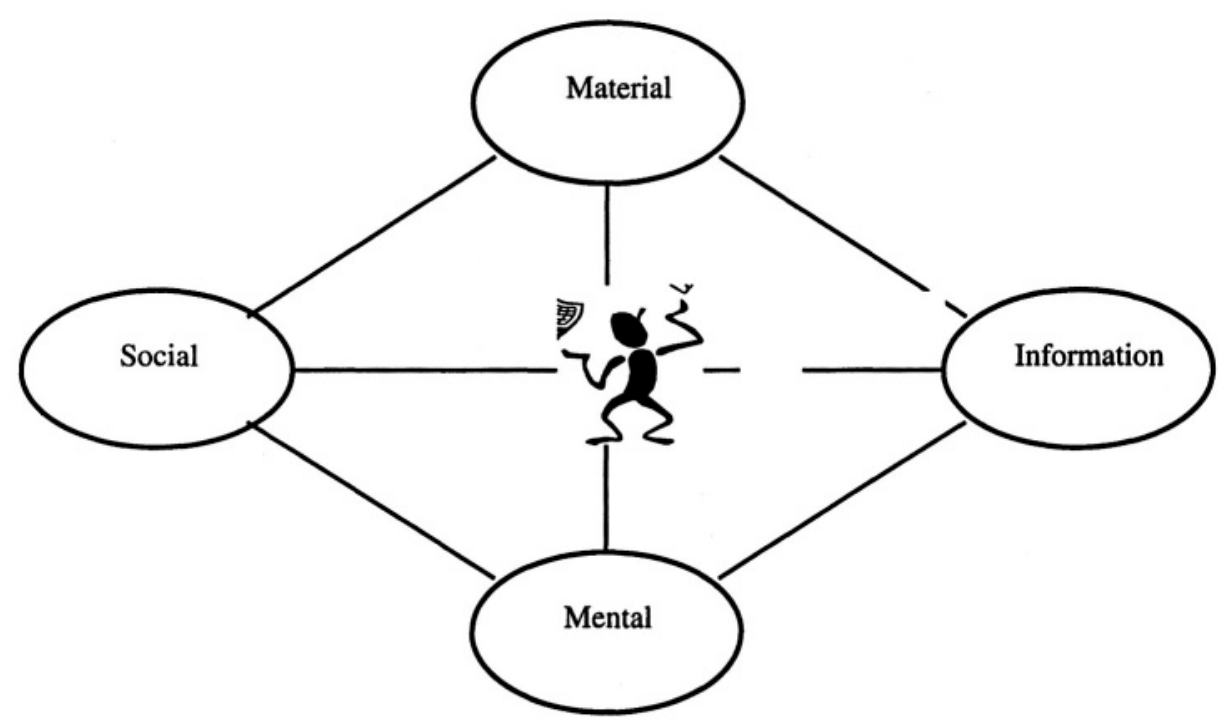

Figure 1. Patterns of polyinclusion in relation to individual learning pathways

(Go \& Van Fenema 2003)

\section{Lifelong Learning}

The emerging patterns of polyinclusion imply the need for integration on two levels. First, at the organisational level it requires the integration of economic, technical and social subsystems. Second, at the (national/regional) community level it requires the integration of cultural, political and economic subsystems (Lievegoed, 1969; p. 27). Patterns of polyinclusion within our society cause a discontinuity that (higher) education can hardly 
respond to in isolation. First, the role and impact of technology has caused the exponential growth of knowledge management, mobile communications and the emergence of networks enhancing the employment perspective of those who are connected and resulting in a digital divide for those who lack the means and skills to be connected. Second, the scale of current economic change, particularly the rapid transition to a knowledge-based economy that is inextricably affected by globalisation and technological revolutions, is driving a 'business as unusual' scenario. Third, just as technological advancement is changing the way we work and learn so too are the attitudes of people as workers, consumers and citizens. This social revolution is occurring at a rapid rate and collides with a demographic time bomb epitomized by an aging population, that will affect both labour and consumer markets.

The European Council has decided that the present situation calls for the introduction of a new approach to education and training. It has resulted in the mandate of the Feira European Council and the Memorandum of Lifelong Learning defined as: "all learning activity undertaken throughout life, with the aim of improving knowledge, skills competence, within a personal, civic, social and/or employment-related perspective."

\section{WHY ARE SOME LEARNING COMMUNITIES MORE VITAL?}

\section{From control to coordination of learning capacity}

In knowledge intensive economies, driven by innovation, the organisation of work is shifting from a resource-based and labour intensive economy to one that is knowledge intensive and requiring new forms of organisation that surround production and work. (Steijn 2001). The traditional hierarchical Tayloristic organisation evolves into one of decisionmaking teams with the following characteristics: (Scheele 1999; pp. 96-97; Theeuwes 2000):

- Flat, with few hierarchical levels.

- Networked, with responsibilities delegated to self-supporting business units, self-controlling teams or autonomous task groups; control and accountability are organised through performance (output) and not by presence or activity (input).

- Close but flexible synchronisation between parts of the primary process, resulting in 'just in time' production (JIT) and lean organisations in 
which minimal stock is kept and with flexible human resource management.

- Working anywhere and anytime, if needed (WRR 2002; p. 148).

Decision-making teams survive by learning from the different viewpoints of team-members and developing a shared perspective. Team learning presupposes social and communication skills (so-called soft skills or people skills), initiative and entrepreneurship, flexibility and reasoned risk-taking. (WRR 2002, p. 148) Furthermore, it implies a need to transform from the current emphasis on control within a single organisation to the coordination of interfacing between learning communities. Innovation is the driving force in the knowledge intensive economy. Organisations need 'business'knowledge that direct and control their 'potential actions'. Knowledge creation can follow four patterns, but in this case requires 'articulation', that is how to transform tacit knowledge (Nonaka \& Takeuchi 1995) residing with the knowledge workers into a "codified, commercially valuable asset." (WRR 2002; p. 22).

\section{Knowledge creation in the Triple Helix}

The importance of knowledge creation within interfacing learning communities calls for the "Making of European Learning Regions', that is regions that are able to create learning opportunities for all its members and transform themselves as a community, as opposed to component parts. Learning regions aim to foster structured collaboration between higher education, business and government resulting in 'cosmopolitan citizenship, informed about the best and most recent knowledge of the time.' (Postman, 1999; p. 82).

Individual learning pathways and learning organisations are significant components of the innovation process (Nonaka and Takeuchi 1995). Community learning affords both individuals and organisations the opportunity to explore, generate new knowledge and apply new knowledge systematically through innovation. It is assumed, that communication of information and knowledge between the various parties involved in the acquisition, generation, and application of new knowledge plays an essential role in the innovation process. Higher education can play a central role in the stages of the explication and transfer of social interaction and knowledge creation (Nonaka and Takeuchi 1995) within social networks designed to stimulate regional innovation.

Knowledge may be understood as the content of learning with behavioural outcomes that reflect the patterns of cognitive associations that have developed (Daft et al, 1984). Knowledge is the result of the interaction 
between tacit (subjective) and codified (objective) components of knowledge. Tacit knowledge is embedded in specific relationships between a number of parties and transferable only within the specific network of interpersonal relationship that is based on commonly shared values at the local level. In contrast, codified knowledge is globally accessible because it is based on a set of assumptions that are commonly accepted independently from the specific membership of the parties'. (Ganzaroli 2002)

Knowledge creation can be interpreted as a four-stage process: socialisation, externalisation, combination, and internalisation. Value can be derived from the knowledge creation process if an organization has the capacity to transfer the potential value that resides within the organization into a value proposition that in turn is perceived external stakeholders to be of value.

Presently, the learning process still depends on tacit knowledge creation that is tied to trust creation, which in turn is derived from socialization and the internalisation of common values and experiences between members of a community of practice. (Nonaka and Takeuchi 1995)

\section{The scientific approach}

The present teaching of subject content puts the emphasis on the "know what", which resides in the model that knowledge is created from information which in its turn is generated from data. Knowledge, however, is part of a 'chain structure' designed to control the actions of the user and has a process oriented character. Higher education pays hardly any attention to enhancing "know how", "know why" and "care why" (Duffy 2001), which nowadays are becoming increasingly important. In contrast to the traditional scientific model, the action research model (Denzin 2000) aims to construct knowledge that is designed to lead to action, or reflection on actions. It rests on a methodical approach that is qualitative in nature and designed to make the process of knowledge creation, -applicability and knowledge validation transparent to the professional or scientific community. "Action Research aims to solve pertinent problems in given contexts through democratic inquiry in which professional researchers cooperate with local stakeholders to seek and enact solutions to problems of major importance to the stakeholders" (Greenwood 2000; p. 96). Action Research is characterized by (Greenwood 2000; p. 96):

- Inquiry in which stakeholders and researchers co - generate knowledge;

- Knowledge constructed in the inquiry leading to action or reflection on actions;

- Diversity in experience and capacity is seen as an enrichment of the process; 
- A method to produce valid research results;

- As a context centred research tool, that is it aims to solve real-life problems within the stakeholder ('s) environment.

Credibility, validity and reliability in action research are measured by the willingness of local stakeholders to act on the research results, thereby risking their welfare on the "validity" of their ideas and the degree to which the outcomes meet their expectations." (Greenwood 2000; p. 96).

Higher education may apply action research to solve real-life problems within its stakeholder(s) environment. The operational nature of knowledge construction in the dominant scientific model can be linked to 'action research', in which constructed knowledge "leads to action, or reflection on action". As a method, action research can be validated, in part, through activity theory, which focuses on 'context centred' problem solving and comprises a tripartite structure in which the relationship between human agent and objects of environment is mediated by cultural means, tools and signs, (www.edu.helsinki.fi/activity/6a/htr). The application of activity theory is relevant because lifelong learning is concerned with: "all learning activity undertaken throughout life." Within an activity theoretical framework, diversity in learning experience and capacity is viewed as an enrichment of the process. It represents an inquiry in which stakeholders and researchers co-generate knowledge and produce valid research results.

Knowledge is co-generated by inquiring stakeholders and researchers (Kemmis and McTaggart 2000), who collect and transfer the information that people store in memory. The latter is a "culturally constructed, social activity" (Arnould, Price and Zinkham 2003; pp. 377-378). What knowledge people construct, "why, and with what effects are the central questions" that sense making is concerned with. Weick $(1995$; p. 4) refers to what investigators have made explicit namely, that sense making "is grounded in both individual and social activity" [...] a process in which individuals develop cognitive maps of their environment (p. 5) "about such things as placement of items into stimuli into frameworks, comprehending, redressing, surprise, constructing meaning, interacting in pursuit of mutual understanding, and patterning" (p. 6).

Currently, activity theory is evolving towards the development of "conceptual tools to understand dialogue, multiple perspectives and voices, and networks of interacting activity systems". This trend is also visible in the digital age, which changes the work and lifestyles as a consequence of emerging polyinclusion patterns. Such issues evoke a need amongst individuals for more flexible learning experiences. 


\section{NEW EDUCATION FOR LIFELONG LEARNING}

Presently, the dominant command organisation seems to be giving way to people working within a community as the "creative source of innovation and enthusiasm for the achievement of a common goal" (Lievegoed 1991; p. 11). Therefore, an important challenge for higher education is "how to integrate successfully, the social subsystem with the economic- and technical subsystem?"

Innovation and learning capacity have driven knowledge economies to "a new limit beyond which they cannot evolve unless they develop a new structure that is based on the new paradigm of dialogue". Such dialogue cannot be achieved simply by maintaining the existing structure and adding human relations. Research into activity theory, indicates that any expansion should "include minimally two interacting activity systems" (www.edu.helsinki.fi/activity/6a/htr). Therefore, a "rethink of the current organizational structure" is required.

As a consequence of the global - local paradox a new education is emerging. In conclusion we shall examine its effects and implications for higher education.

\section{Implications for Higher Education}

At the global level, higher education (Blake \& Go 2002) is affected, by the "international restructuring race" (Ruigrok \& van Tulder 1995), within a borderless supply chain framework. That is, organizations are continuously engaged in competition with existing and new entries and the opportunities and the need for co-operation. Multiple stakeholders with diverse backgrounds, interests and aims have become involved in the design and delivery of curricula, including, corporations, business associations and nongovernmental organisations (NGOs). The faster pace of knowledge creation, transfer and application, the dynamism of shifting relationships and increase in costs has a considerable impact on higher education. The emerging extended higher education network that is emerging within flexible, interfacing learning communities has its roots in ICT and the concept of lifelong learning.

At the local level, one of the salient characteristics of higher education institutions is that they typically serve a particular region. In order to be successful such institutions must create feelings of belonging and motivate students to attend the local higher educational institution. Despite the information age higher education is likely to become "more physically embedded in, and intellectually intertwined with, the community. Another way of saying this is that [higher] education will become more local." 
(Ritzer 1998; p. 158) and integrated in the sense described by Lievegoed (1969) and further explored by Etzkowitz \& Leydesdorff (2001) with reference to the Triple Helix, that is, the intertwining of higher education with industries and the government within partnerships.

How can the development of Triple Helix partnership under conditions of dynamic convergence and divergence create leverage for lifelong learning, both for individuals and communities? For higher education to achieve leverage for lifelong learning joint sense making is needed as practiced within decision-making teams, leading to a collective identity: Who are we? Where do we come from? Where are we going? Wenger (1998) distinguished three processes, which contribute to the formation of collective identity: (1) engagement; (2) imagination and (3) alignment. Each of these points deserves some further investigation.

\section{Engagement to redefine Higher Education}

Presently, higher education is largely unable to accommodate the higher expectations from higher education by society. It faces increasing numbers of learners and learning needs and rising capital and operating costs. The large scale automation of traditional education, including textbook, classroom and teacher, will not resolve the present problem." (Visser 1999; p. 2) "Universities, and other learning institutions, are in need of redefining themselves in much more fundamental ways than by simply continuing their old practices by modern means. The production of knowledge has become a highly networked and increasingly fluid phenomenon. Universities play a role in it, but are no longer the exclusive or even major players. They are in need of continually repositioning themselves. Gibbons refers to the valueadded inherent in the "creativity to configure knowledge and resources over and over again". Such networks of knowledge production are likely to comprise more than just the academic community" (Visser 1999; p. 4) Engagement refers to processes designed to accomplish a sense of connectedness. The identification with a group comes about typically through face-to-face experiences. It may include processes such as the definition of common goals with partners; participation in network activities and social interactions; the production of recognizable symbols and the exchange of ideas to bring about a sense of community. The perceived collective identity should be carefully examined to comprehend both opportunities and limitations of development. 


\section{Imagining the future of Higher Education}

Recent developments in international business and politics drive home the notion that local and global issues are inextricably intertwined. The future of higher education is therefore tied with the global-local paradox and therefore a subject of consequence and key agenda item. Scenarios and the reinterpretation of experiences and using such history to place and interpret the future in a different frame are part of the process of imagination. It affords people the opportunity to scan new situations, take risks, and develop connections and to position themselves in an alternate context. Through the extrapolation of one's own experiences, the identity of higher education can take on new dimensions. For example, through a scenario of educating modern professionals, who must become engaged in lifelong learning, students actually become a knowledge node or bridge between business, government and higher education. Through the application of Action Research methodology an open learning system can be created which, on the basis of a socialization process, supports the students' learning and tests the knowledge they develop in terms of quality and reliability. Subsequently, the knowledge thus acquired is integrated in the process of knowledge generation, knowledge development and knowledge application, or the articulation, leading to new combinations (Nonaka \& Takeuchi 1995) that is an integral part of higher education.

\section{Alignment of Higher Education within Agile Learning Community}

Last but not least, processes such as convincing, inspiring, uniting and identifying boundaries of partnerships and the definition of visions are important for the coordination of decision making teams. Energy and activities have to fit within a broader organisational structure. Virtual learning organisations provide an extension of the work environment and therefore provide a fit with patterns of polyinclusion. The Web enterprise of agile organization (Metselaar \& van Dael 1999) is an ICT-supported temporary network of experts working in a specific field or on a specific topic. "...a spatially dispersed and temporarily flexible cultural community, the reproduction of which is dependent upon learning and innovation of its constituents." (McLouhglin \& Jackson 1997) Knowledge management and the sharing of information among partners are essential elements for an agile organisation. (Metselaar \& van Dael 1999; p. 204)

ICT acts as a powerful enabler to develop partnerships, learning organisations, and learning communities between partners with different 
characteristics such as business, universities and local government. But ICT is only one part of an economic subsystem that must be integrated with the cultural - and political subsystem at (national) community level (Lievegoed 1969 ; p. 27) in order to deliver the competences that society needs. In a knowledge driven network centric economy the vitality of (national) communities is determined by organisation that "makes for a maximum of flexibility" (Lievegoed 1969; p. 11) that helps to bridge the digital divide and affording both individuals and learning communities alike access to lifelong learning.

\section{CONCLUSION}

Successful learning communities appear to reside in the ability to create and sustain a learning culture; that is to enable human talent to develop a competitive edge through the application of advanced technology, knowledge and service. There is a dangerous gap between what the knowledge economy needs of higher education and the "competences" the latter delivers that can be bridged by lifelong learning, which builds on connectivity, knowledge and learning capacity, and is E-readiness enabled. Furthermore, successful learning communities seize the opportunity that partnership provides, resulting in a so-called triple helix that is a platform uniting higher education business and government to support the process of lifelong learning. Finally, successful learning communities understand that lifelong learning implies the need for engagement to redefine the tasks of all community stakeholders, but particularly higher education to bring about an image of a new higher education future, engagement to redefine and align higher education within agile learning communities.

\section{REFERENCES}

Arnould, E., L. Price \& G. Zinkhan (2003) Consumers. McGraw Hill, New York.

Bell, D (1988) The World in 2013, Dialogue 81 (3) pp.3-9.

Blake, C. \& F. Go (2002) Stimulating e-learning in Europe: A Supply Chain Approach Erasmus University, Rotterdam.

Campbell, A. (1997) Knowledge management in the virtual enterprise, in: Jackson, P. \& J. van der Wielen (Eds.) (1997) Proceedings of the Second International Workshop on Telework: "Building actions on ideas", WORC, Tilburg University, The Netherlands, pp. 15-25. 
Commission of the European Communities (2000) A Memorandum on Lifelong Learning 30.10.2000, SEC(2000) 1832, Brussels.

Daft, R.L. \& K.E. Weick (1984) Towards a model of organizations as interpretation system. Academy of Management Review 9 (4), pp. 284-295.

D’Aveni, R (1994) Hypercometition: Managing the dynamics of strategic manoeuvring. Free Press, New York.

Denzin, N. K. \& Y. S. Lincoln (Eds.) (2000) Handbook of qualitative research, second edition. Sage Publications, Thousand Oaks/London/New Delhi, p. 85 - 106.

Duffy, Th. M. \& Ch. Orrill (2001) Constructivism, in Kovalchic A. \& K. Dawson (Eds.), Educational Technology, An Encyclopedia. ABC-CLIO, Santa Barbara CA.

Etzkowitz, Henry \& Loet Leydesdorff (2001) Universities and the Global Knowledge Economy A Triple Helix of University-Industry-Government Relations. Continuum, London.

Greenwood, D. J. \& M. Levin (2000) Reconstructing the relationships between universities and society through action research. In: Denzin, N. K. \& Y. S. Lincoln (Eds.) Handbook of qualitative research, second edition, Sage Publications, Thousand Oaks/London/New Delhi, p. $85-106$.

Janszen, F (2000) The age of innovation Financial Times, London.

Kemmis, S. and R. McTaggart, R. (2000) Participatory action research. In; Denzin, N. and Y. Lincoln (Eds) Handbook of Qualitative Research (2nd. Ed.) Sage, Beverley Hills CA, pp. 567-605.

Lievegoed, B (1991) Managing the Developing Organisation. Basil Blackwell, Oxford.

Lievegoed, B (1969) Organisaties in Ontwikkeling. Lemniscaat, Rotterdam.

McLoughlin, I. \& P. Jackson (1997) Organisational learning and virtual technologies: Towards a research agenda. In: Jackson, P. \& van der Wielen, J. (eds.) (1997) Proceedings of the Second International Workshop on Telework: "Building actions on ideas", WORC, Tilburg University, The Netherlands, p.p. 37 -53.

Metselaar, C. \& R. van Dael (1999) Organisations going virtual, AI \& Soc (1999) 13, p.p. 200 -209 .

Nonaka, I. \& H. Takeuchi (1995) The Knowledge Creating Company. Oxford University Press, Oxford.

Peppers, D \& M. Rogers (1993) The one-on-one future: building business relationships one customer at a time. Piatkus, London. 
Porter, M.E. (1998) What is strategy? In: On Competition, Harvard Business Review, Boston, pp. 39-73.

Postman, Neil (1999) Building a Bridge to the Eighteenth Century. Knopf, New York.

Ritzer, George (1998) The McDonalization Thesis. Sage, London.

Ruigrok, W. \& R. Tulder (1995) The logic of international restructuring. Routledge, London.

Scheele, D. (1999) Arbeid en vaardigheid: een literatuurstudie naar veranderingen in arbeidsvaardigheden, WRR Werkdocument nr. W103, Wetenschappelijke Raad voor het Regeringsbeleid, Den Haag

Steijn, B. (2001) Werken in de informatiesamenleving, Koninklijke van Gorcum, Assen.

Tapscott, D. (1996) Digital Economy, Promise and peril in the age of networked intelligence. McGraw-Hill, New York.

Theeuwes, J. J. M. (2000) Chips, bits en jobs. Infodrome (www.infodrome.nl)

Visser, J. (1999) Changing learning environments: The real and not so real of reality and virtuality. Learning without frontiers, Unesco, Paris (www.unesco.org/education/lwf)

Weick, K (1995) Sensemaking in organizations. Sage, London.

Wenger, E (1998) Communities of Practice: The social fabric of a learning organization. Cambridge University Press, New York.

Wetenschappelijke Raad voor het Regeringsbeleid (WRR) (2002) Van oude en nieuwe kennis, De gevolgen van ICT voor het kennisbeleid. Sdu Uitgevers, Den Haag. Reports to the government 61, Of old and new knowledge, the consequences of ICT for knowledge policy (http://www.wrr.nl/en/frameset.htm) 